\title{
Comparison of the Effect of Different Heat Treatment Processes on Microstructure and Mechanical Properties of Stainless Steel Clad Plate
}

\author{
H. R. Jin, ${ }^{\mathrm{a}, \mathrm{b}, 1}$ X. K. Yang, ${ }^{\mathrm{c}}$ and Y. L. Yi \\ ${ }^{a}$ Key Laboratory of Advanced Forging \& Stamping Technology and Science, Ministry of Education \\ of China, Yanshan University, Qinhuangdao, China \\ b Parallel Robot and Mechatronic System Laboratory of Hebei Province, Yanshan University, \\ Qinhuangdao, China \\ ${ }^{c}$ School of Mechanical Engineering, Yanshan University, Qinhuangdao, China \\ ${ }^{1}$ ysujhr@ysu.edu.cn (H. R. Jin)
}

To improve the mechanical properties and corrosion resistance of $304 / Q 345 R$ stainless steel clad plate, different heat treatment processes (oil cooling, oil cooling and tempering, oil cooling to $450^{\circ} \mathrm{C}$ as well as air cooling) have been performed after hot rolling. The microstructure, mechanical properties and corrosion resistance have been analyzed after conducting air cooling and heat treatment. The precipitated phases near the cladding interface have been measured using the energy spectrum analysis. The results imply that after hot rolling and air cooling the base layer microstructure is composed of ferrite and pearlite layers, while the overall strength of the clad plate remains to be low. The corrosion resistance is shown to be insignificant due to the higher precipitation of $\mathrm{Cr}$ carbide on the stainless steel side. After oil cooling, the hard phases of martensite and bainite dominate in the base layer microstructure. The plate strength has been enhanced, but its plasticity is insufficient. After tempering, the ductility value is considerably improved, however, it still fails to satisfy the requirements. After being oil cooled to $450^{\circ} \mathrm{C}$ and air cooled, the microstructure is found to be mainly composed of bainite, ferrite, and a small amount of pearlite. The clad plate mechanical properties, such as strength, plasticity as well as corrosion resistance, have been significantly enhanced.

Keywords: heat treatment, stainless steel clad plate, microstructure, mechanical properties, corrosion resistance.

Introduction. The stainless steel clad plate is a new type of highly efficient and energy-saving material with the stainless steel clad layer and the low-alloyed steel base layer, which exhibits excellent mechanical properties and high corrosion resistance. It has a widespread use in metallurgy, electric power, petrochemical and other fields [1]. But in practice, due to intergranular corrosion, the stainless steel clad plate corrosion resistance is insufficient. Therefore, heat treatment requires the corrosion resistance enhancement [2]. In recent years, there has been a considerable interest in investigating the heat treatment process effect on the metal material microstructure and properties [3-5]. The variation of the microstructure, physical and chemical properties of the $\mathrm{Al} / \mathrm{Ti}-6 \mathrm{Al}-4 \mathrm{~V}$ clad plate has been investigated under different heat treatment processes. The $\mathrm{Ti} / \mathrm{Al}$ metallurgical bonding interlayer at the clad plate interface has been obtained under the optimized friction stir lap welding (FSLW) process condition [6]. The Ti steel explosive rolling clad plate has undergone heat treatment at various temperatures. The results imply that the heat treatment makes it possible to greatly enhance the diffusion and the microstructure transformation [7]. The heat treatment process of three clad plates has been studied, and the residual stresses have been analyzed [8]. The effects of different heat treatment processes on the microstructure and the mechanical properties of the stainless steel clad plate have been studied [9]. The corrosion in the stainless steel clad plate with different heat treatment has been analyzed. The analysis shows that the optimal heat treatment process of the stainless 
steel clad plate involves $(620 \pm 10)^{\circ} \mathrm{C} / 4 \mathrm{~h}$ and air cooling [10]. Heat treatment has shown its significance at providing and improving the clad plate quality. Different heat treatment processes exert various effects on the clad plate properties, thus, the development of appropriate heat treatment process for the clad plate is not required. For the cladding layer cooled within the sensitization temperature range the supersaturated carbons in grains combine with chromium ions to form the chromium carbide, which causes the grain boundary chromium depletion as well as intergranular corrosion defect $[11,12]$. For the base layer, better mechanical properties can be obtained via thermal refining or slow cooling [13]. Therefore, an effective heat treatment is required to be performed on the stainless steel clad plate to ensure both the corrosion resistance and better mechanical properties.

This paper presents three heat treatment processes considering the cooling feature of the base layer (Q345R) and sensitization curve of the clad layer (304). The optimum heat treatment process of 304/Q345R stainless steel clad plate is selected using the comparative analysis of the microstructure and the general properties, which provides the theoretical background and the experimental data for the industrial manufacture of the stainless steel clad plate.

1. Materials and Methods. The base layer (Q345R low alloy steel) and the clad layer (304 stainless steel) chemical compositions are listed in Table 1. A square groove was cut in the middle of the base slab. A hydrochloric acid pickle dilute was applied. Acetone was used to clean the composite interface. The two symmetrical stacked layers were sealed around via welding and vacuumed to $10^{-2} \sim 10^{-1} \mathrm{~Pa}$. Before being hot rolled, the composite ratio of the stainless steel clad plate comprised 1:9. The Q345R billet was of $300 \times 300 \times 90 \mathrm{~mm}$ in size, while the $316 \mathrm{~L}$ billet - of $300 \times 300 \times 10 \mathrm{~mm}$ in size. The billets were heated to the temperature of $1100 \sim 1200^{\circ} \mathrm{C}$ for $15 \mathrm{~min}$ and hot-roll boned to obtain the final dimensions of the clad plate $(800 \times 400 \times 25 \mathrm{~mm})$. Figure 1 illustrates the images of the stainless steel clad plate before and after hot rolling.

T a b 1 e 1

Chemical Base and Clad Layers' Compositions (\%)

\begin{tabular}{|c|c|c|c|c|c|c|c|c|c|}
\hline Material & $\mathrm{C}$ & $\mathrm{Si}$ & $\mathrm{Mn}$ & $\mathrm{P}$ & $\mathrm{S}$ & $\mathrm{Ni}$ & $\mathrm{Cr}$ & $\mathrm{Al}$ & $\mathrm{Fe}$ \\
\hline Q345R & 0.150 & 0.35 & 1.4 & 0.020 & 0.0025 & - & - & 0.028 & Bal. \\
\hline 304 & 0.065 & 0.75 & 1.2 & 0.034 & 0.0056 & 8.05 & 17.0 & $<0.010$ & Bal. \\
\hline
\end{tabular}

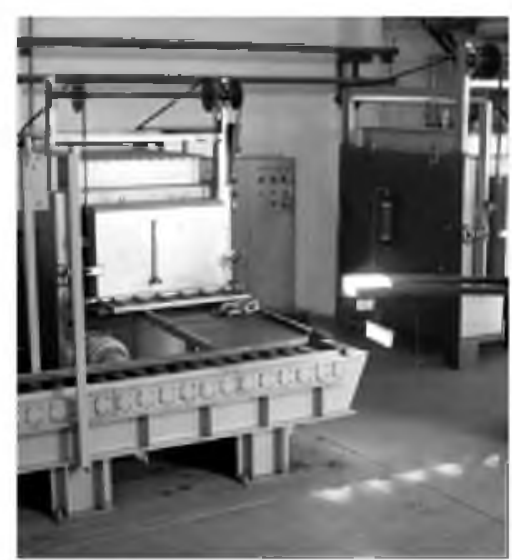

a

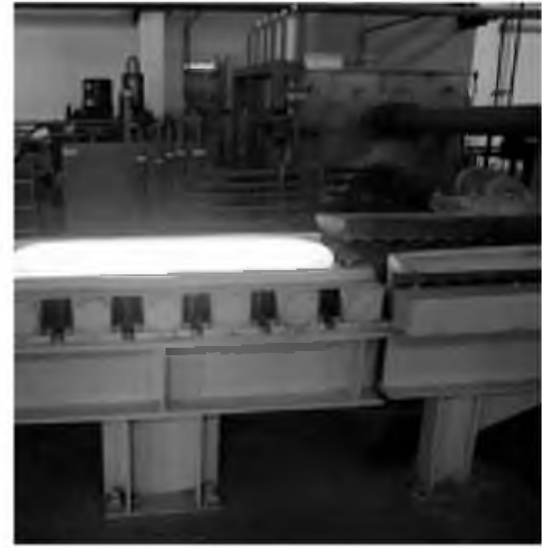

b

Fig. 1. Rolling stainless steel clad plate specimen: before (a) and after (b) hot rolling. 
Chromium depletion at the grain boundaries caused by the long retention time of stainless steel in the sensitization temperature range $\left(450 \sim 850^{\circ} \mathrm{C}\right)[14,15]$ leads to the intergranular corrosion. To ensure the corrosion resistance of stainless steel, rapid cooling is required to prevent the sensitization. For low-alloyed steel, hardness, strength as well as wear resistance can be improved by rapid cooling, while gradual cooling can reduce the residual stress and improve plasticity. Three were three heat treatment processes: oil cooling $\left(1000^{\circ} \mathrm{C} \times 60 \mathrm{~min}\right)$, oil cooling $\left(1000^{\circ} \mathrm{C} \times 60 \mathrm{~min}\right)$ accompanied with tempering $\left(500^{\circ} \mathrm{C} \times 30 \mathrm{~min}\right)$, oil cooling $\left(1000^{\circ} \mathrm{C} \times 60 \mathrm{~min}\right)$ to $450^{\circ} \mathrm{C}$ followed by air cooling (Table 2$)$.

$\mathrm{T}$ a b 1 e 2

Specimens Heat Treatment

\begin{tabular}{|c|c|c|c|c|c|c|}
\hline Process & $\begin{array}{c}\text { Temperature } \\
\left({ }^{\circ} \mathrm{C}\right)\end{array}$ & $\begin{array}{c}\text { Holding } \\
(\mathrm{min})\end{array}$ & Cooling & $\begin{array}{c}\text { Temperature } \\
\left({ }^{\circ} \mathrm{C}\right)\end{array}$ & $\begin{array}{c}\text { Holding } \\
(\mathrm{min})\end{array}$ & Cooling \\
\hline Hot rolling & - & - & Air cooling & - & - & - \\
\hline Oil cooling & 1000 & 60 & Oil cooling & - & - & - \\
\hline $\begin{array}{c}\text { Oil cooling }+ \\
\text { tempering }\end{array}$ & 1000 & 60 & Oil cooling & 500 & 30 & Air cooling \\
\hline $\begin{array}{c}\text { Oil cooling + } \\
\text { air cooling }\end{array}$ & 1000 & 60 & $\begin{array}{c}\text { Oil cooling } \\
\text { to } 450^{\circ} \mathrm{C}\end{array}$ & - & - & Air cooling \\
\hline
\end{tabular}

After polishing of specimens, the cladding layer was etched with aqua regia. The base layer was etched with a $4 \%$ nitric acid alcohol solution. Then ( 5 s later), the specimens were rinsed with alcohol and dried with an ordinary air blower. Sampling position in the middle zone of the stainless steel clad plate with distinct gradation, clear alloy phase and obvious grain boundaries were selected for the microstructure observation and the composition analysis using 200MAT metalloscope and EDX, respectively. The shear and tensile strength values were obtained via tension-shear tests complying with the specifications in GB/T6396-2008. The corrosion resistance of the cladding layer was evaluated by the test method B of GB/T4334-2008.

\section{Results and Discussion.}

2.1. Microstructure of the Base Layer. Figure 2 illustrates the base layer microstructure transformation before and after different heat treatment processes. After hot rolling and air cooling, granular ferrite and lamellar pearlite were formed due to slow cooling rate shown in Fig. 2a. After oil cooling, the microstructure was found to be composed mainly of hard phase martensite and bainite, as is shown in Fig. 2b. Due to fast cooling rate, the grain size was much smaller than that during air cooling, and the grains were found to be refined. Figure $2 \mathrm{c}$ shows the microstructure after oil cooling and tempering, which consists of the tempered martensite and tempered bainite with the grains of uniform dimensions. Figure $2 \mathrm{~d}$ depicts the microstructure after oil cooling to $450^{\circ} \mathrm{C}$ and air cooling, which mainly consists of bainite, ferrite, and a small amount of pearlite.

2.2. Microstructure of the Cladding Layer. The microstructures of the cladding layer before and after different heat treatments (Fig. 3) are composed of single coarse-grained austenite of regular polygon shape. After hot rolling and air cooling, the grain boundaries were clearly visible and appear as black lines with fine particle distribution caused by carburization. Some grains underwent recrystallization. The continuous distribution of the twin boundary in grains was observed in Fig. 3a. Relatively few twin crystals with grain boundaries (light-colored) were observed, and no carbide particles were precipitated after oil cooling $\left(1000^{\circ} \mathrm{C} \times 60 \mathrm{~min}\right)$, as shown in Fig. $3 \mathrm{~b}$. After oil cooling $\left(1000^{\circ} \mathrm{C} \times 60 \mathrm{~min}\right)$ and tempering $\left(500^{\circ} \mathrm{C} \times 30 \mathrm{~min}\right)$, the grain dimensions were increased at the grain 


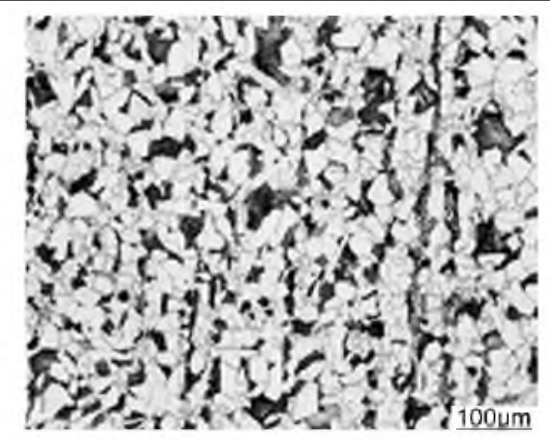

a

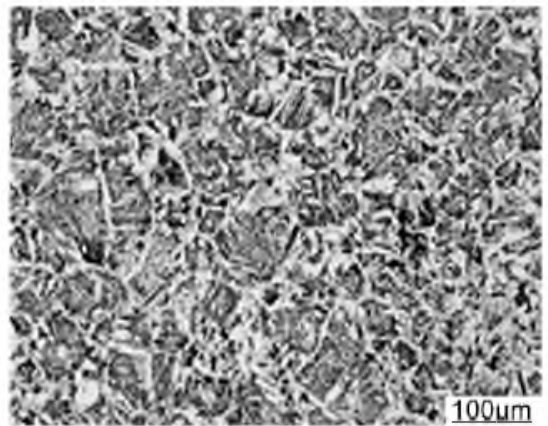

$\mathrm{c}$

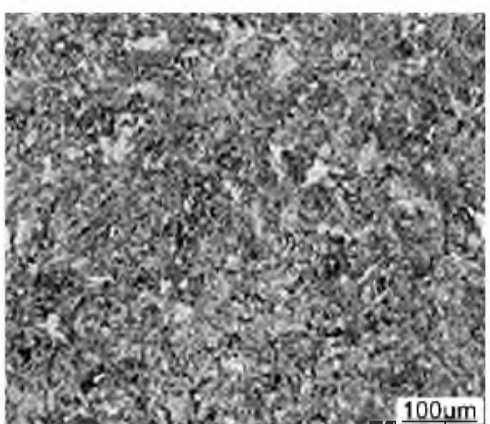

b

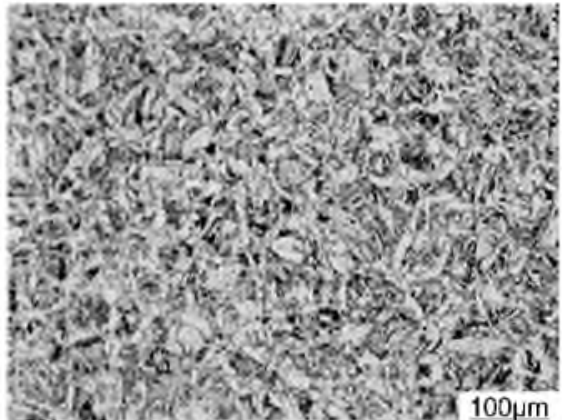

d

Fig. 2. Microstructure of the base layer after different heat treatments. Here and in Figs. 3 and 4 : (a) hot rolling; (b) oil cooling; (c) oil cooling + tempering; (d) oil cooling + air cooling.

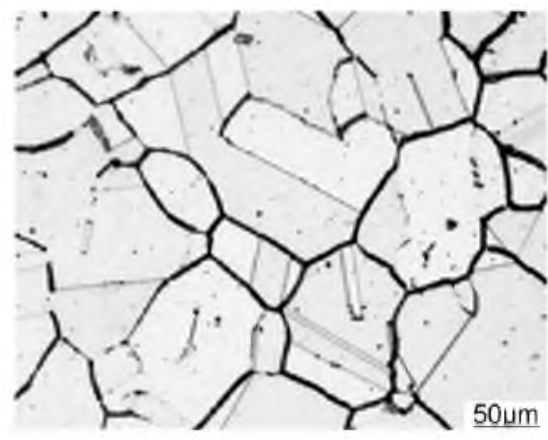

a

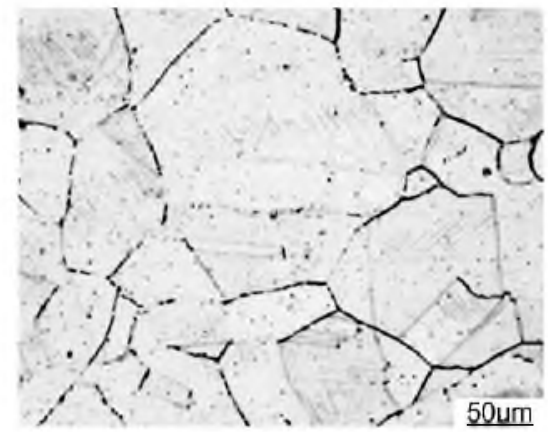

$\mathrm{c}$

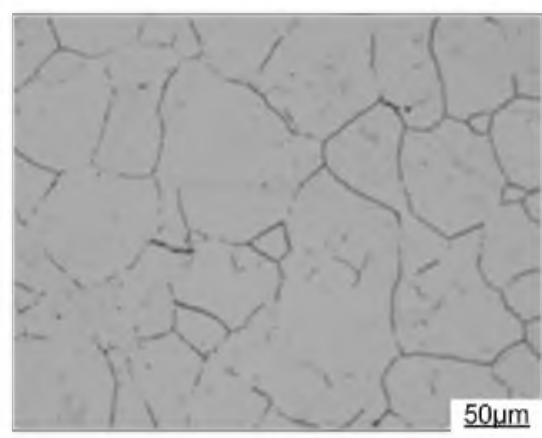

b

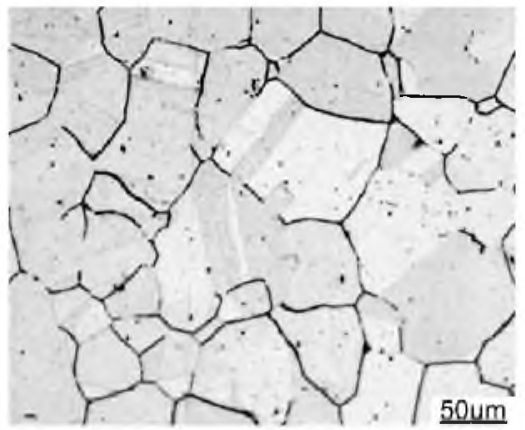

d

Fig. 3. Microstructure of the clad layer after different heat treatments. 
boundaries, and a small amount of fine carbide was distributed, as shown in Fig. 3c. Figure $3 \mathrm{~d}$ illustrates the microstructure after oil cooling $\left(1000^{\circ} \mathrm{C} \times 60 \mathrm{~min}\right)$ to $450^{\circ} \mathrm{C}$ and air cooling. At the high temperature stage, oil cooling mode was adopted. The sensitization temperature zone was avoided due to the fast cooling rate, and few carbide particles were observed to be precipitated. At the low temperature stage, the austenite dimensions were increased without gradient microstructure, while the twin crystal dimensions were decreased.

2.3. Mechanical Properties of the Stainless Steel Clad Plate. The shear strength $\left(\sigma_{c}\right)$, yield strength $\left(\sigma_{s}\right)$, tensile strength $\left(R_{m}\right)$, elongation $(\delta)$, and impact energy $(W)$ were obtained in the shear, tensile and impact testing shown in Table 3 . In compliance with GB/T $8165-2008$, the minimum value of the shear strength is $210 \mathrm{MPa}$, the yield strength is $345 \mathrm{MPa}$, the tensile strength is $510 \mathrm{MPa}$, the elongation is $21 \%$, and the impact energy is $34 \mathrm{~J}$. The shear strength is the performance factor to measure the interface bonding property, which directly affects the composite material use. Although the shear strengths of the clad plate were different before and after heat treatment processes, they were all greater than $210 \mathrm{MPa}$ and met the requirements of the interface combination. The highest shear strength of specimens equal to $446 \mathrm{MPa}$ was attained by oil cooling $\left(1000^{\circ} \mathrm{C} \times 60 \mathrm{~min}\right)$ to $450^{\circ} \mathrm{C}$ and air cooling. After oil cooling and tempering $\left(500^{\circ} \mathrm{C} \times 30 \mathrm{~min}\right)$, the shear strength slightly decreased, as compared with that one after oil cooling due to the interfacial residual stress release and the element diffusion caused by tempering. At oil cooling $\left(1000^{\circ} \mathrm{C} \times 60 \mathrm{~min}\right)$, the microstructure of the specimen was mainly composed of brittle and hard martensite exhibiting high yield strength and tensile strength, but low elongation, impact energy, and toughness. After oil cooling followed by tempering and air cooling, the elongation and the impact energy were increased, but the strength and elongation could not meet the specific requirements. After oil cooling $\left(1000^{\circ} \mathrm{C} \times 60 \mathrm{~min}\right)$ to $450^{\circ} \mathrm{C}$ and air cooling, the values of strength, plasticity and toughness of the specimens were in good agreement with the standard ones.

$\mathrm{T}$ a b 1 e 3

Mechanical Properties of the Specimens

\begin{tabular}{|c|c|c|c|c|c|}
\hline Specimens & $\sigma_{c}, \mathrm{MPa}$ & $\sigma_{s}, \mathrm{MPa}$ & $R_{m}, \mathrm{MPa}$ & $\delta, \%$ & $W, \mathrm{~J}$ (at $0^{\circ} \mathrm{C}$ ) \\
\hline Hot rolling & 402 & 320 & 511 & 32.4 & 55 \\
\hline Oil cooling & 436 & 596 & 802 & 11.9 & 19 \\
\hline $\begin{array}{c}\text { Oil cooling }+ \\
\text { tempering }\end{array}$ & 424 & 598 & 664 & 14.6 & 154 \\
\hline $\begin{array}{c}\text { Oil cooling }+ \\
\text { air cooling }\end{array}$ & 446 & 364 & 558 & 22.2 & 146 \\
\hline
\end{tabular}

2.4. Corrosion Resistance of the Stainless Steel Clad Plate. The stainless steel clad plate corrosion resistance depends on the clad layer due to the chromium element facilitating the steel passivation and ensuring its stability. With the longer sensitization temperature zone $\left(450 \sim 850^{\circ} \mathrm{C}\right) \mathrm{Cr}_{7} \mathrm{C}_{3}, \mathrm{Cr}_{23} \mathrm{C}_{13}$ and other relatively stable carbides are formed due to the combination of oversaturated carbons and chromium ions at the grain boundaries with a large amount of chromium ions separated out. This results in the decrease of the chromium content at the grain boundaries and the intergranular chromium depletion, which damages the intergranular corrosion resistance of stainless steel and even leads to the failure of stainless steel layer. The corrosion resistance can be ensured by adopting the heat treatment to avoid the sensitization temperature zone. 
The composition and content of the precipitated phase near the composite interface using the energy spectrum analysis are shown in Fig. 4, including $\mathrm{C}, \mathrm{O}, \mathrm{Fe}, \mathrm{Si}, \mathrm{Cr}, \mathrm{Mn}, \mathrm{Al}$, $\mathrm{Mg}, \mathrm{Ti}$, and $\mathrm{Ca}$. Figure 4a demonstrates the composition and content after hot rolling and air cooling with a high amount of chromium (approximately $10.98 \mathrm{wt} \%$ ) due to the slow air cooling rate. The small carbon atoms possess strong diffusion ability in metal. The carbon elements of the base layer were diffused into the interface and the cladding layer. The oversaturated carbons of the austenite grains in the cladding layer were precipitated to be combined with the chromium ions to form the stable high chromium carbide, causing the reduction of chromium ions and weakening of the stainless steel clad plate corrosion resistance. Figure $4 \mathrm{~b}$ provides the point energy spectrum analysis results for the specimens after oil cooling $\left(1000^{\circ} \mathrm{C} \times 60 \mathrm{~min}\right)$ with only $3.45 \mathrm{wt} \%$ content of chromium due to redissolution of carbides in the microstructure after $1000^{\circ} \mathrm{C}$ solution treatment to alleviate the intergranular chromium depletion. The spectrum analysis results are shown in Fig. 4c after oil cooling $\left(1000^{\circ} \mathrm{C} \times 60 \mathrm{~min}\right)$ and tempering $\left(500^{\circ} \mathrm{C} \times 30 \mathrm{~min}\right)$. This is explained by the fact that after tempering the temperature was increased to accelerate the diffusion rate of elements. The carbon atoms were easily combined with the chromium at the grain boundaries, and the carbide increase at the interface was observed. The spectrum analysis results after $\left(1000^{\circ} \mathrm{C} \times 60 \mathrm{~min}\right)$ oil cooling to $450^{\circ} \mathrm{C}$ and air cooling are presented in Fig. $4 \mathrm{~d}$. By analyzing the content and the composition at the interface, it can be concluded that chromium carbide was partially dissolved to reduce the chromium content after different heat treatment processes and ensure the stainless steel clad plate corrosion resistance.

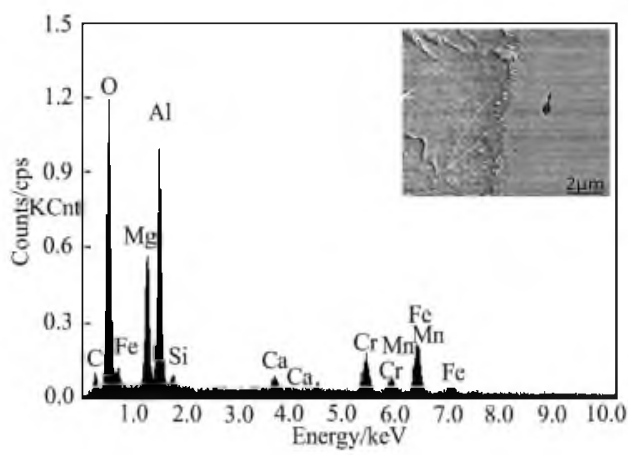

a

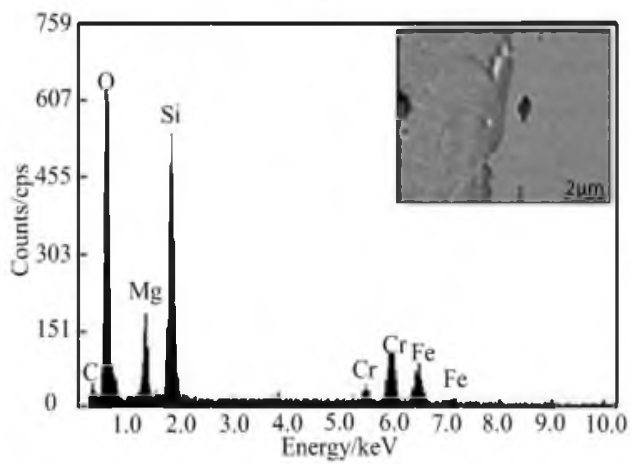

c

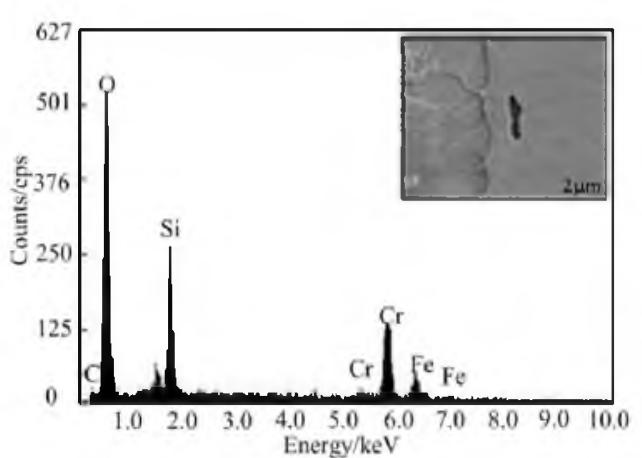

b

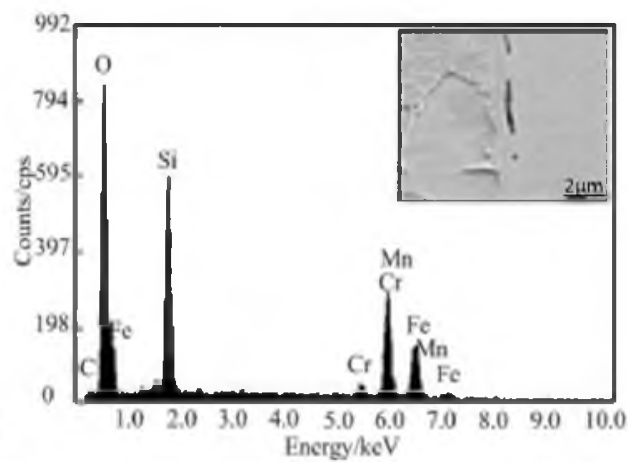

d

Fig. 4. The energy spectrum analysis for different heat treatments.

The cladding layer corrosion rate was tested based on the experimental scheme B of GB/T4334-2008, as shown in Fig. 5. 


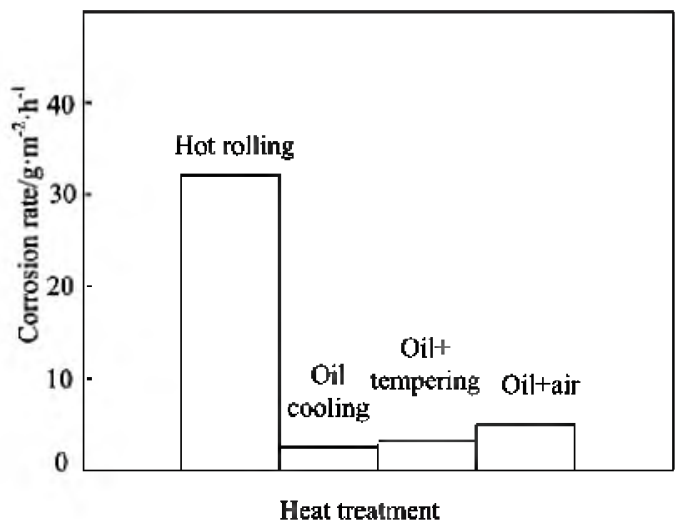

Fig. 5. Corrosion rate of the clad layer under different heat treatment.

The corrosion resistance was low after hot rolling and air cooling due to the fast corrosion rate. It was mainly caused by the precipitation of chromium carbide at longer exposure within the sensitization temperature zone due to the slow cooling rate, which led to serious intergranular chromium depletion and affected the corrosion resistance of the stainless steel clad plate. After three heat treatment processes, the corrosion rate was decreased by one order of magnitude, while the corrosion resistance was improved significantly. During the heat treatment fast cooling rate causes shorter exposure at the sensitization temperature to ensure the chromium content and improve the corrosion resistance.

In conclusion, after hot rolling and air cooling, the overall strength and corrosion resistance of the clad plate were insufficient with the residual stress within the plate that affected the good combination of interface. After oil cooling $\left(1000^{\circ} \mathrm{C} \times 60 \mathrm{~min}\right)$, the overall strength and corrosion resistance of the clad plate were improved. But the plasticity and toughness values were inconsiderable due to the hard phase microstructure development. Finally, the plasticity value was enhanced, but still failed to meet the practical requirements. After oil cooling $\left(1000^{\circ} \mathrm{C} \times 60 \mathrm{~min}\right)$ to $450^{\circ} \mathrm{C}$ and air cooling, the mechanical properties and the corrosion resistance were found to be excellent and could satisfy the performance requirements.

\section{Conclusions}

1. After hot rolling and air cooling, the base layer microstructure was mainly composed of granular ferrite and lamellar pearlite, which have a negative effect on the overall mechanical properties of the clad plate failing to meet the requirements. After hot rolling, the carbon atoms with the higher diffusion capacity were prone to diffuse to form the chromium carbide. The content of $\mathrm{Cr}$ was the highest (approximately $10.98 \mathrm{wt} \%$ ) using the energy spectrum analysis, which causes the intergranular chromium depletion and seriously impairs the corrosion resistance.

2. After oil cooling $\left(1000^{\circ} \mathrm{C} \times 60 \mathrm{~min}\right)$, the hard microstructure, such as martensite, was formed due to the fast cooling rate. Since the strength and corrosion resistance values were improved, the elongation and the impact energy values were decreased (about $11.9 \%$ and $19 \mathrm{~J}$ ), which could not satisfy the requirements. After tempering, the base layer microstructure was composed of the tempered martensite and tempered bainite. The plasticity and corrosion resistance values were improved, however, failed to meet the requirements. After oil cooling $\left(1000^{\circ} \mathrm{C} \times 60 \mathrm{~min}\right)$ to $450^{\circ} \mathrm{C}$ and air cooling, the base layer microstructure was found to be composed of bainite, ferrite, and little pearlite. The clad plate with the high strength, good plasticity and excellent corrosion resistance demonstrated better overall mechanical properties. 
3. Considering such factors as the corrosion resistance of the cladding layer, the mechanical properties of the base layer, heat treatment operation and cost, the optimum heat treatment for the clad plate is found to be oil cooling $\left(1000^{\circ} \mathrm{C} \times 60 \mathrm{~min}\right)$ to $450^{\circ} \mathrm{C}$ and air cooling.

Acknowledgments. This project was supported by the Joint Fund for Iron and Steel Research of the National Natural Science Foundation of China and Baosteel Group Corporation (Grant No. U1660111) and the Natural Science Foundation-Steel and Iron Foundation of Hebei Province (Grant No. E2014203118).

1. Y. A. Jing, Y. Qin, X. M. Zang, et al., "A novel reduction-bonding process to fabricate stainless steel clad plate," J. Alloy. Compd., 617, 688-698 (2014).

2. P. Tamilchelvan, K. Raghukandan, and S. Saravanan, "Optimization of process parameters in explosive cladding of titanium/stainless steel $304 \mathrm{~L}$ plates," Int. J. Mater. Res., 104, 1205-1211 (2013).

3. Y. Kobayashi, M. Honda, and Y. Kaneko, "Corrosion resistant type 310 stainless steel clad plate," NKK Tech. Rev., 57, 98 (1989).

4. C. S. Kim, S. J. Moon, W. S. Kong, "Effect of sensitization treatment on corrosion properties in austenitic stainless steel 304," Mater. Sci. Forum, 857, 232-236 (2016).

5. L. Paul and C. Prothe, "Effect of heat treatment on nickel alloy clad plates," Riv. Ital. Saldatura, 67, 487 (2015).

6. B. Li, Y. F. Shen, L. Luo, and W. Y. Hu, "Effects of processing variables and heat treatments on $\mathrm{Al} / \mathrm{Ti}-6 \mathrm{Al}-4 \mathrm{~V}$ interface microstructure of bimetal clad-plate fabricated via a novel route employing friction stir lap welding," J Alloy. Compd., 658, 904-913 (2016).

7. H. T. Jiang, X. Q. Yan, J. X. Liu, and X. G. Duan, "Effect of heat treatment on microstructure and mechanical property of Ti-steel explosive-rolling clad plate," Trans. Nonferr. Metal. Soc., 24, No. 3, 697-704 (2014).

8. B. Mateša, D. Kozak, A. Stoić, and I. Samardžić, "The influence of heat treatment by annealing on clad plates residual stresses," Metalurgija, 50, No. 4, 227-230 (2011).

9. H. Y. Liu, X. J. Zhang, and L. Li, "Effects of heat treatment on microstructure and properties of hot rolled stainless steel clad plate," Heat Treat. Met., 6, 67-71 (2013).

10. H. B. Yang, "Analysis on corrosion resistance of stainless steel clad plate with different heat treatment," Hot Working Technol., 4, 240 (2016).

11. O. V. Kasparova, "Peculiarities of intergranular corrosion of silicon-containing austenitic stainless steels," Prot. Met., 40, No. 5, 425-431 (2004).

12. R. G. De Paula, C. R. Araujo, V. de F. C. Lins, and J. R. G. Carneiro, "Corrosion resistance of explosion cladding plate of carbon steel and $316 \mathrm{~L}$ stainless steel," Corros. Eng. Sci. Techn., 47, No. 2, 116-120 (2012).

13. Y. H. Wang and X. C. Jia, "Effects of heat treatment process on microstructure and properties of low-alloy steel," Foundry Technol., 4, 429 (2013).

14. W. C. Jiang, Y. Luo, H. Wang, and B. Y. Wang, "Effect of impact pressure on reducing the weld residual stress by water jet peening in repair weld to 304 stainless steel clad plate," J. Press. Vess.-T. ASME, 137, No. 3, 031401 (2015).

15. E. R. Hwang and S. G. Kang, "Intergranular corrosion of stainless steels in molten carbonate salt," J Mater. Sci. Lett., 16, No. 16, 1387-1388 (1997). 